\title{
A házinyulak nagyüzemi tartásának minimális állatvédelmi követelményei - a WRSA Magyar Tagozatának ajánlása
}

\author{
Szendrő Zsolt* \\ Kaposvári Egyetem Agrár- és Környezettudományi Kar, 7400 Kaposvár, \\ Guba S. 40.
}

\section{ABSTRACT - Minimum requirements of welfare for housing of rabbits on large-scale farms - recommendations of the Hungarian Branch of WRSA}

Author: Zsolt Szendrő

Affiliation: Kaposvár University Faculty of Agricultural and Environmental Sciences, 7400 Kaposvár, Guba S. street 40., Hungary

The Hungarian Branch of WRSA formulated the minimum requirements of welfare for housing of rabbits in large-scale farms. These are as follows.

\section{General recommendations}

- The farmers are obliged to keep the animals in accordance with the scientific knowledge and experience and the genotype, age, physiological status and behavioural needs. Attention needs to be paid on: provision of adequate housing system to meet the environmental requirements of the animals; provision of sufficient space, feed and water for the animals; care them according to welfare requirement; with attention to the behavioural and social needs of the animals. Any person working with the animals has to receive instructions and guidance on the relevant provisions and complete appropriate training in particular focus on welfare aspects.

- Animal accommodation should be designed and managed to meet species-specific needs, and can not be contrary to any of the five freedoms of the animals.

- The buildings have to be constructed and maintained so that the risk of fire is minimised. The materials used should be fire-resistant.

- Avoid causing unnecessary pain, suffering or injury of the animals.

- Animals and any technological equipment used in rabbit farm should be inspected at least once a day, and any malfunctions should be eliminated immediately.

- The cages or pens of rabbits should be designed to meet the breed, age, sex, and physiological state.

- The cages or pens should be constructed of durable, impervious materials and designed and continuously maintained so that they do not cause injury of animals, and the animals are free from pain and injuries whilst taken in and out of the cage.

- The cages or pens have to be clearly arranged, and easy to control.

- Floors of cages must ensure that the droppings fall out of the cage, and the animals do not contact with manure.

- Feeding and watering systems have to be constructed, placed, operated and maintained to meet the physiological needs of the animals; reduce feed waste, leakage or contamination of the water, each animal should have sufficient access opportunities, so avoiding competition among animals for feed or water; do not cause injury of the animals; the feed and water consumption can be controlled.

- Permanent access to a sufficient quantity of fresh water has to be provided. The feeders and drinking systems have to be checked daily.

- Before the introduction of a new stock of the rabbits, the house/cages should be thoroughly cleaned and disinfected. 
- All-in all-out management is recommended to improve rabbit health, where rabbits are produced in one batch on a 6 week (or similar) cycle allowing the rabbit building to be vacated for a short period for intensive cleaning and disinfection.

- Only skilled persons are permitted to work with direct contact to the rabbits. Care of the rabbits can only be carried out by a person who has adequate theoretical and practical knowledge of that breed, age group and the used management in order to be able to detect the cause of behavioural changes in the animals and their health status.

- If it is suspected that the animal is not healthy or the behaviour appears to change adversely, the farmer has to eliminate the cause without delay, and if necessary, call a veterinarian. If necessary, the sick or injured animal has to be separated.

- The farmer has to register the number of rabbits, the animal losses, the treatments, disinfection, production and stock change (selling and buying) in the record keeper in a daily basis.

- Keeping rabbits in buildings with continuous high noise levels would be avoided. While rabbits can be scared by sudden noise, a continuous music can have a positive effect.

\section{General rules for rabbit does, bucks, suckling and growing rabbits}

- The air flow rate (maximum $0.4 \mathrm{~m} / \mathrm{sec}$ ), dust level, relative humidity (between 55 and 85\%), the concentration of carbon dioxide (maximum $0.002 \%$ Vol.) and ammonia (maximum $0.3 \%$ Vol.) should be at a level which is not harmful to rabbits.

- The air temperature should be between $10{ }^{\circ} \mathrm{C}$ and $28^{\circ} \mathrm{C}$. The minimum temperature for does at time of kindling is $15^{\circ} \mathrm{C}$.

- Rabbits are active from late afternoon till early morning; however, suitable lighting is necessary for them (minimum 30 and 10 lux for breeding does and growing rabbits, respectively), but protection against bright light should be provided for them. At least a daily continuous 8-hour dark period should be provided.

- Keeping rabbits in cages with solid walls without visual connection is prohibited, except bucks mainly at the time of mating and semen collection.

- Floors of cages and pens must be smooth but not slippery to prevent injuries of the rabbits and so designed, constructed and maintained as not to cause injuries or suffering of the animals.

- The dead rabbits must be removed immediately from the cage.

- Rabbits should have permanent access to a sufficient quantity of material, such as wood, straw, hay, or other material, which does not compromise the health of the animals, to enable proper investigation and manipulation activities and gnaw it. Gnawing sticks or other chewable materials are recommended for rabbit does, bucks and growing rabbits.

- Using a dual system in rabbit farms is recommended to decrease the stress at weaning. These systems are used for does with their kits, and after weaning the growing rabbits stay in the original cage and does are moved into a clean and disinfected cage before kindling.

- Environmental pollution of the rabbit farms have to be decreased.

\section{The minimum requirements for housing of rabbit does}

- Future breeding female rabbits have to be housed individually after the age of 12 weeks because of the high incidence of aggressiveness, fighting and injuring.

- At present, all cages are accepted which are produced by large cage factories in Europe, these cages can be found in several European rabbit farms, if its floor size is minimum $38 \times 87 \mathrm{~cm}$ and its height is minimum $32 \mathrm{~cm}$ ). The minimum requirement is that the floor area allows the does to turn around easily and lie in stretched position.

- When using a wire-mesh floor, it is necessary to provide at least a $25 \times 40 \mathrm{~cm}$ sized plastic-mesh footrest for the does for preventing the sore hocks.

- Elevated platforms in cages or pens of rabbit does are recommended because they give larger possibility for moving than the flat-deck cages. 
- Group-housing of rabbit does is not recommended, because of aggressiveness, fighting, injuries and stress.

- A nest box or nesting part in the cage has to be provided for rabbit does. The basic area size of the nest box for a medium-sized doe is at least $800 \mathrm{~cm}^{2}$ with a shorter side of minimum $38 \mathrm{~cm}$.

- The nest box or nest tray has to be given at least three days before the expected parturition to have enough time for does to prepare a good quality nest.

- For the nest-building suitable nesting material (e.g. wood shavings, hay, strax) in sufficient quality and quantity must be given.

- The possibility of closing the nest box should be provided by a door for using controlled nursing.

- The nest should be clearly arranged, and the kits in it have to be checked daily.

\section{The minimum standards for housing of bucks}

- Future breeding male rabbits have to be housed individually after the age of 10 weeks to avoid aggressiveness, fighting and castration.

- The minimum requirement is that the floor area allows the bucks to easily turn around and lie in stretched position. The minimum floor size is $50 \times 64 \mathrm{~cm}$, and $40 \mathrm{~cm}$ height.

- Plastic-mesh floor is recommended; however, when using a wire-mesh floor, it is necessary to provide at least a $25 \times 40 \mathrm{~cm}$ sized plastic-mesh footrest for preventing the sore hocks.

\section{The minimum standards for housing of growing rabbits}

- The cages or pens for growing rabbits can be up to maximum three-storey for the proper checkability of the animals.

- No individual housing of growing rabbits is allowed, except aggressive or sick animals.

- The smallest group size is 2-3 rabbits per cage. In case of larger group, it is not recommended to house animals from more than one litter (8-10 rabbits) in a cage or pen, because in large groups the risk of infection, stress and aggressiveness is higher.

- The stocking density at the end of the fattening period should not exceed 16 rabbits $/ \mathrm{m}^{2}$ or $45 \mathrm{~kg} \mathrm{rab}-$ $\mathrm{bit} / \mathrm{m}^{2}$.

- The height of 30-35 cm for fattening cages/pens is acceptable because rabbits prefer covered places.

- Deep litter floor is not recommended because growing rabbits refuse staying on it, animals can consume from the litter material mixed with manure and urine, and the risk of diseases and mortality is higher.

- Wire-mesh and plastic-mesh floors are accepted.

- When growing rabbits are kept in groups they are fed using a system which ensures that each individual can obtain sufficient food even when competitors for the food are present. A $10 \mathrm{~cm}$ wide feeder is enough for 10 growing rabbits. If the size of the group is larger, the size of the feeder should be increased proportionally.

- When growing rabbits are kept in groups such a drinking system should be used which ensures that each individual can obtain sufficient water even when competitors for the water are present. Ten growing rabbits should reach at least two nipple drinker. If the group size is larger, the number of drinkers should be increased.

We agree with the text of European Parliament resolution of 14 March 2017 on minimum standards for the protection of farm rabbits (2016/2077(INI)). It pointed out that "a balance must be kept between the various aspects to be taken into consideration, as regards animal welfare and health, the financial situation and working conditions of farmers, sustainability of production, environmental impact and consumer protection; points out also that account must be taken of consumer needs for affordable, high-quality rabbit meat." Namely, changing housing system is high cost for the farmer, so a financial assistance is necessary to farmers by Commission to support the rabbit farming sector in future EU budgets.

Keywords: rabbit, housing, welfare, requirements 


\section{BEVEZETÉS}

Az európai fogyasztók egyre nagyobb hangsúlyt helyeznek az állatok jóllétére. Az elvárások megfogalmazásában jelentős szerepe van az állatvédő mozgalmaknak, amelyek egy része szakmai ismeretek, mások viszont érzelmi benyomások alapján fogalmazzák meg véleményüket. Sajnos ritkán jutnak el a kutatási eredmények a kereskedőkhöz és a fogyasztókhoz, az állatvédők viszont nagyon eredményesen gyakorolnak nyomást a kereskedelemre, a politikusokra, és végül a fogyasztók választását is hatékonyan befolyásolják.

Ugyanakkor az állatjólléti előírásoknak kutatási eredményeken kellene alapulniuk, valóban az állatok jóllétét kellene szolgálniuk, figyelemmel a termelőre és a fogyasztói árakra is. A nyulak védelmére vonatkozó minimális követelményekről szóló, az Európai Parlament 2017. március 14-i állásfoglalásában (2016/2077 (INI)) rámutattak arra, hogy „számos szempont mérlegelésével egyensúlyt kell tartani, figyelemmel az állatok jóllétére és egészségére, a gazdálkodók pénzügyi helyzetére és a munkakörülményekre, a termelés fenntarthatóságára, a környezeti hatásra és a fogyasztóvédelemre, továbbá a fogyasztók megfizethető, jó minőségű nyúlhús iránti igényére".

A házinyulak tartásával és jóllétével kapcsolatban számos tudományos cikk, irodalmi összefoglaló és tanulmány jelent meg (EFSA, 2005; Hoy és mtsai, 2006; Trocino és Xiccato, 2006; Verga és mtsai, 2009; Szendrő és Dalle Zotte, 2011; Szendrő és McNitt, 2012; Szendrő és mtsai, 2016; Hoy és Matics, 2016; González-Mariscal és mtsai, 2017; Turner és mtsai, 2017; Szendrő és mtsai, 2019).

A fogyasztók igényeinek kielégítése érdekében az Európai Unió Tanácsa (EU Tanácsa) irányelveket adott ki a tenyésztés céljából tartott állatok védelméről (Council Directive 98/58/EC of 20 July 1998), a tojótyúkok, (Council Directive 1999/74/EC of 19 July 1999), a hústermelés céljából tartott csirkék (Council Directive 2007/43/EC of 28 June 2007), a borjak (Council Directive 2008/119/EC of 18 December 2008), valamint a sertések védelmére vonatkozó minimális követelményekről (Council Directive 2008/120/EC of 18 December 2008). Az EU Tanácsa azonban még nem tett közzé semmilyen előírást a tenyésztett nyulak védelméről.

Jelen cikk célja, hogy tudományos eredményekre alapozva foglalja össze a házinyulak nagyüzemi tartásának minimális követelményeit. Nemcsak a követelményeket írjuk le, hanem ahol van, röviden összefoglaljuk az adott terület irodalmi eredményeit, vagyis a javaslatok magyarázatát is.

A minimális követelmények „A mezőgazdasági haszonállatok tartásának állatvédelmi szabályairól” szóló 32/1999. (III. 31.) FVM rendeletre, illetve annak 
módosított változataira (20/2002. (III. 14.) FVM rendelet, 72/2004. (IV. 29.) FVM rendelet, 178/2009. (XII. 29.) FVM rendelet) épülnek. Ugynakkor független a sokkal szigorúbb állatkísérletekről szóló 40/2013. (II. 14.) Korm. rendelettől.

\section{A WRSA MAGYAR TAGOZATÁNAK AJÁNLÁSAI}

\section{1. Általános ajánlások}

- Az előírásokat csak a legalább 120 anyanyulat vagy 1000 hízónyulat tartó telepekre kell alkalmazni.

- A különböző alternatív (márkázott) tartási rendszerek magasabb szintű elvárásokat fogalmazhatnak meg, mint amit a minimális követelményekben írnak elő.

- A gazdáknak megfelelő ismeretekkel és tapasztalattal kell rendelkezniük a nyulak fajtájával, korával, fejlettségével, élettani állapotával és viselkedési szükségleteivel kapcsolatban. Bármely más, az állatokkal foglalkozó személynek is ismerni kell a vonatkozó rendelkezéseket, különös tekintettel az állatjólléti szempontokra.

- A nyulakat az állatfaj igényének megfelelően kell elhelyezni, és a jó gazda gondosságával kell őket kezelni.

- Nagyüzemi (nem alternatív) tartás esetén a nyulakat beltéri, zárt helyiségben kell tartani.

- Az épületeket úgy kell megépíteni és karbantartani, hogy minimális legyen a tűzveszély, továbbá legyenek felszerelve tűz- vagy füstriasztóval.

- Csökkenteni kell a nyúltelep által okozott környezeti terhelést.

- A tartás helyén a levegő hőmérsékletének $10^{\circ} \mathrm{C}$ és $28^{\circ} \mathrm{C}$ között kell lennie. A fialó anyanyulak, szopósnyulak, valamint a választott növendéknyulak tartási helyén viszont legalább $15^{\circ} \mathrm{C}$-ot kell biztosítani. A megfelelő, az ideálishoz közeli hőmérséklet biztosításához télen és nyáron az istállók klimatizációjáról gondoskodni kell.

Megjegyzés: Az újszülött nyulaknak, az elletôládában $38^{\circ} \mathrm{C}$ körül alakul az optimális hömérsékletigénye, ami 14 napos korra $30^{\circ} \mathrm{C}$-ra csökken (Hull és mtsai, 1986), majd tovább csökkenve, a hizlalás végére 15 és $25{ }^{\circ} \mathrm{C}$ közé esik (Cervera és Fernández Carmona, 2010), ami az anyanyulak igényénél kissé alacsonyabb. A magas hömérséklet jelent nagyobb gondot, mert a bundában levő nyulaknak alig van izzadtságmirigyük (Brewer és Cruise, 1994), elsősorban a fül vérerei segítségével szabályozzák a test hömérsékletét (Lukefahr és Ruiz-Feria, 2003). 
- Az istállóban a légáramlás sebessége legfeljebb 0,4 m/sec, a relatív páratartalom 55 és 85\% között, a szén-dioxid legfeljebb 0,002 térfogatszázalék, az ammónia 0,30 térfogatszázalék, az egyéb gázok és a por koncentrációja olyan mértékű legyen, amely nem káros a nyulakra.

Megjegyzés: A légáramlás sebessége függ a hömérséklettől: 10-15 ㄷ között 0,1-0,15 $\mathrm{m} / \mathrm{sec}, 15-19{ }^{\circ} \mathrm{C}$ között 0,15-0,20 m/sec, 19-23 ${ }^{\circ} \mathrm{C}$ között 0,2-0,3 m/sec, 23-26 ${ }^{\circ} \mathrm{C}$ között 0,3-0,4 m/sec. Ugyanezekhez a hömérséklet-tartományokhoz tartozó levegő szükséglet, sorrendben 1-2; 2-3, 3-3,5 és 3,5-4 m³óra/testsúly kg. Az ideális és az elfogadható relatív páratartalom tenyésztistállóban 65-70\% illetve 55-85\%, hizlaló istállóban 55-70\%, illetve 50-85\%. Hoy és Lange (1997) legfeljebb 0,002 térfogatszázalék ammónia és 0,30 térfogatszázalék széndioxid szintet javasol. Érdemes figyelembe venni, hogy más állatfajokhoz viszonyítva a házinyúl nem érzékeny a magas széndioxid szintre, mert az üregi nyúl az üregrendszerben magas széndioxid tartalmú levegőben tartózkodik, ami toleránssá tette a széndioxiddal szemben (Hayward és Lisson, 1978).

- Gondoskodni kell az állatok igényének megfelelő megvilágításról: anyanyulaknak legalább 30 lux, növendéknyulaknak 10 lux fényerősség szükséges, az erős fénnyel szemben ugyanakkor védelmet kell nyújtani. Naponta legalább 8 óra folyamatos sötét időszakot kell az állatok számára biztosítani.

Megjegyzés: Az üregi és a házinyulak sötétben aktívak, nappal pihennek (Prud'hon és mtsai, 1975; Villafuerte és mtsai, 1993; Diez és mtsai, 2005). Több szakkönyv 30-50 lux fényintenzitást javasol (Lebas és mtsai, 1997; Schlolaut, 1998; EFSA 2005).

- Ne tartsák a nyulakat túl zajos helyen. Mivel a hirtelen zajtól megijedhetnek, ezért ennek hatását csökkenthetjük, ha az állatok például állandóan zenét hallhatnak.

- Kerülni kell az állatok szükségtelen fájdalmát, szenvedését vagy sérülését.

- A ketreceket vagy fülkéket úgy kell megtervezni, hogy megfeleljenek a fajta, az életkor, az ivar és az élettani szükségleteknek, és könnyen ellenőrizhetők, tisztíthatók legyenek.

- A ketreceket vagy fülkéket úgy kell kialakítani és folyamatosan karbantartani, hogy azok ne okozhassanak sérülést az állatoknak, emellett az állatok fájdalom- és sérülésmentesen legyenek kivehetők a ketrecből vagy fülkéből. 
- Lemez, vagy más átláthatatlan oldalfalú ketrecben nyulat tartani - kivéve bakok, különösen fedezéskor és ondóvételkor - tilos. Biztosítani kell az állatok számára, hogy láthassák fajtársaikat.

Megjegyzés: Az üregi nyúl számára a túlélés miatt fontos, hogy jól belássák a környezetüket és időben vegyék észre a ragadozót. A nem túl sürü bozótos területet kedvelik (Lombardini és mtsai, 2003). Ha a ketrec fala tömör, ez akadálya a vizuális kapcsolatnak és megijedhetnek, ha az épületben levő személyt csak a ketrec fölé érkezéskor látják meg (Szendrő és Dalle Zotte, 2011). Drótrácsoldalfal esetén látják, és jobban érzik a szomszédos ketrecekben levő nyulak szagát, emellett - a fal két oldalán feküdve - a szociális kapcsolat szempontjából fontos test-kontaktus is megfigyelhető.

- A ketrecek és fülkék padozata legyen sima, csúszásmentes, ne okozzon talpfekélyt, és úgy alakítsák ki, hogy ne érintkezzenek az állatok az ürülékkel.

- Rácspadozat alkalmazásakor a hosszanti huzalok távolsága nem haladhatja meg a $20 \mathrm{~mm}$-t, a kereszthuzalok távolsága az $55 \mathrm{~mm}-\mathrm{t}$, a dróthuzal átmérője legalább $2 \mathrm{~mm}$ legyen.

- Az állatok új helyre telepítése előtt a tartási helyeket alaposan ki kell takarítani és fertőtleníteni.

- Az egészség védelme, a betegségek terjedésének megelőzése céljából az egyszerre telepítés, egyszerre ürítés (all-in all-out) rendszer ajánlott.

Megjegyzés: Kettős használatú ketrecben (dual purpose cage) választáskor a kisnyulak helyben maradnak, és a vemhes anyanyulak kerülnek egy másik épület tiszta ketrecébe. Ezáltal kisebb a választási stressz és betegség fellépésének kockázata. Vágáskor kiürülnek a ketrecek és ekkor kerül sor - az all-in all-out rendszernek megfelelően - a teljes épület és a berendezési tárgyak alapos takarítására és fertôtlenítésére (Hoy és Matics, 2016).

- Az állományt naponta kell ellenőrizni. Gondoskodni kell a beteg állatok kezeléséről, lehetőség szerint az elkülönítéséről. Az elhullott egyedeket azonnal el kell távolítani.

- Az etetőket és itatókat olyan méretben és számban kell a ketrecbe helyezni, hogy a nyulak könnyen, egymást nem zavarva férjenek hozzájuk. Az esetleges meghibásodás miatt minden ketrecbe két itatószelepet kell tenni. Az etetők és az itatók kialakítása olyan legyen, hogy a takarmány és az ivóvíz ne szennyeződjön, a takarmány- és ivóvízveszteség minimális legyen.

- Az etetőket és az itatókat naponta kell ellenőrizni. A meghibásodást lehetőleg azonnal meg kell szüntetni. 
- Rágófa vagy más rágható anyag használata ajánlott, különösen csoportos tartás esetén.

Megjegyzés: A nyulaknak lehetőleg állandó hozzáférést kell biztosítani olyan anyaghoz, mint pl. rágófa, szalma, széna vagy más anyag, amellyel foglalkozhatnak, amit megrághatnak, sốt el is fogyaszthatnak, és nem veszélyezteti az állatok egészségét. Környezetgazdagítással csökkenthető az unatkozás, javulnak a nyulak életkörülményei (Verga és mtsai, 2009). A rágófának általában nincs negatív hatása a termelésre (Verga és mtsai, 2004; Princz és mtsai, 2007, 2009). Legnagyobb elönye, hogy csökken az agresszív viselkedés gyakorisága és a sérülések száma, különösen, ha puhafából készülnek a rágófák (Princz és mtsai, 2008a)

\section{Az anyanyulak tartásának minimális követelményei}

- 12 hetes kortól a tenyésznövendék-, majd az anyanyulakat egyedileg kell elhelyezni, hogy megelőzhetőek legyenek az agresszív viselkedés miatti verekedések és sérülések.

Megjegyzés: Mirabito és mtsai (2005) négyesével neveltek együtt nőivarú nyulakat, de - sérülés miatt - tenyésztésbevételig a nyulak harmadát kellett selejtezni.

- Jelenleg valamennyi nagy európai ketrecgyártó által forgalmazott tenyészketrec mérete elfogadható, ha az alapterülete legalább 38x87 cm és 32 cm magas.

Megjegyzés: Kis ketrecben korlátozott az anyanyulak mozgási lehetôsége, ami frusztrálhatja őket és sztereotip viselkedés (pl. fémrács rágása) fordulhat eló (Verga és mtsai, 2007). Bár a legtöbb kísérlet szerint a ketrecméret nem befolyásolja az anyanyulak termelését (Mirabito és mtsai, 2005; Rommers és Meijerhof, 1998); a nagyobb ketrec több mozgási lehetöséget és kényelmesebb elhelyezést nyújt (Szendrő és McNitt, 2012). Véleményünk szerint az eddig elfogadott minimális, elletőládán kívül legalább $3000 \mathrm{~cm}^{2}$ terület szúk, de ennél nagyobb alapterületü ketrec cseréjéhez támogatás szükséges. Amennyiben az EU bármilyen a jelenleginél nagyobb minimális ketrecméretet határozna meg, a kertecek cseréjéhez elegendö átmeneti idôt kell hagyni és támogatást kellene nyújtani. Az Európában használt ketrecek méretét az 1. táblázat mutatja.

- Az anyanyulak ketrecébe polc behelyezése javasolt.

Megjegyzés: A polc nagyobb mozgási lehetôséget, fel- és leugrást biztosít. Elvileg az anyanyúl el tud menekülni az elletőládát már elhagyó, szopni akaró kisnyulak elól (Mirabito és mtsai, 1999), de 3 hetes kortól a szopósnyulak is fel tudnak menni a polcra (Mirabito és mtsai, 1999, 2004; Mikó és mtsai, 2014). Emiatt mégsem csökken a szopás miatti zavarások száma (Mirabito és mtsai, 2004). Ugyanakkor Mikó és mtsai (2014) kísérletében az egyszintes ketrechez képest nőtt a 3 hetes alomsúly. Legjobb, ha a polc müanyag rácsból készül, és az alsó szinten is van pihenőlap. 


\section{1. táblázat}

Az európai nagy nyúltelepeken jelenleg használt egyedi tenyészketrecek méretei

\begin{tabular}{lcccc}
\hline Ketrec típusa & $\begin{array}{c}\text { Szélesség } \\
\text { (cm) }\end{array}$ & $\begin{array}{c}\text { Hosszúság } \\
\text { (cm) }\end{array}$ & $\begin{array}{c}\text { Magasság } \\
\text { (cm) }\end{array}$ & $\begin{array}{c}\text { Alapterület } \\
\text { (cm²) }\end{array}$ \\
\hline $\begin{array}{l}\text { Fiatal és nem vemhes anya } \\
\begin{array}{l}\text { Szoptató anyanyúl kisnyulakkal } \\
\text { (standard és kettős célra) }\end{array}\end{array}$ & 38 & 43 & 35 & 1600 \\
$\begin{array}{l}\text { Szoptató anyanyúl kisnyulakkal } \\
\text { (kettős célra) }\end{array}$ & 38 & $87^{*}$ & 32 & 3300 \\
$\begin{array}{l}\text { Szoptató anyanyúl kisnyulakkal } \\
\text { (gazdagított ketrec) 20 cm } \\
\text { széles fémrácspolccal }\end{array}$ & $38 / 46$ & $102,5^{*}$ & 61 & 3600 \\
$\begin{array}{l}\text { Szoptató anyanyúl kisnyulakkal, } \\
\text { műanyagrács polccal (kettős } \\
\text { célra) }\end{array}$ & 52,5 & $102,5^{*}$ & 97 & $4650 /$ \\
\hline
\end{tabular}

*Fészek beleszámítva. **A polc alapterülete is beleszámítva. Forrás: Szendrő és mtsai, 2019

Table 1. The dimensions of the cage which are used in the European large rabbit farms at the moment ${ }^{*}$ calculated with the basic area of nest box; ${ }^{* *}$ calculated with the basic area of elevated platform. Source: Szendrő et al, 2019

- Az agresszív viselkedés, verekedés, sérülés és stressz miatt az anyanyulak csoportos tartása nem javasolt.

Megjegyzés: Ha az anyanyulak folyamatosan együtt vannak, gyakori a verekedésekre visszavezethetố sérülés és az álvemhesség miatti gyenge vemhesülés, két anyanyúl azonos elletôládába fialhat, részben emiatt nő a szopóskori elhullás, a folyamatos stressz miatt az anyanyulak rövidebb ideig élnek (Mirabito és mtsai, 2005; Rommers és mtsai, 2006; Andrist és mtsai, 2013; Szendrő és mtsai, 2013). Ezek a problémák a csoportban élő üregi anyanyulaknál is megfigyelhetők: gyakori a verekedés (Southern, 1948; von Holst és mtsai, 1999), a másik anya újszülött nyulainak elpusztítása, nő az alárendelt nyulakban a stresszhormonszint, valamint kevesebb nyulat fialnak és nevelnek fel (von Holst és mtsai, 2002; Rödel és mtsai, 2004, 2008).

Félig csoportos tartás esetén, az anyanyulak a fialás elötti néhány naptól 3 hétig egyedi ketrecekben vannak, majd az oldalfalak kivételével a négy anyanyúl és a kisnyulak 3 hétig ugyanabban a fülkében vannak csoportosan (elválasztás után a növendéknyulakat itt nevelik fel). Bár a termelési eredmények hasonlóak lehetnek az egyedi tartáshoz (Maertens és mtsai, 2011; Maertens és Buijs, 2015), de minden csoportosítás után - rövidebb vagy hosszabb ideig - heves verekedés és sok sérülés 
fordul elő. Az agresszív viselkedés és a sérülések gyakoriságának csökkentése érdekében több módszert próbáltak ki (polc, PVC-csövek betétele, szalma, sötét folyosó, a csoport-kialakítás a korábbi vagy új fülkében, illatanyag permetezése az állatokra stb.), de nem, vagy alig tudták csökkenteni az agresszivitást, 40-60\%-ban találtak sérült nyulakat (Graf és mtsai, 2011; Andrist és mtsai, 2012, 2013, 2014; Rommers és mtsai, 2011, 2013). Mindez ellentétes az állatjólléttel, az állatok öt szabadságjogával. A 70-es években Franciaországban épp emiatt szüntették meg az anyanyulak csoportos tartását (Mirabito és mtsai, 2005).

Nem szabad megfeledkezni arról, hogy az üregi nyulak - több más állatfajhoz hasonlóan - azért élnek csoportban, mert így nagyobb a ragadozókkal szembeni túlélési esélyük (több szem, többet lát, hátulsó lábukkal dobbantva figyelmeztetik a társakat a veszélyre, cikk-cakkban futva menekülnek be a közösen kiásott üregrendszerbe) (Cowan, 1987; König, 1997). A csoportban élésnek tehát több az előnye, mint a hátránya (Ebensperger és Wallem, 2002). Az istállókban viszont nincs ragadozó, csak a csoportban élés hátrányai jelentkeznek.

- A fialó anyanyulaknak elletőládát kell betenni, vagy fialó részt kell kialakítani. Az elletőláda mérete középtestű anyanyulak esetén legalább 800 cm², egyik oldala legalább $38 \mathrm{~cm}$ hosszú legyen.

Megjegyzés: Az üregi anyanyulak egy kisméretü, gömb alakú, kb. $25 \mathrm{~cm}$ átméröjü fialóüreget készítenek (Lloyd és McCowan, 1968). Az elletőládának (fészeknek) elég nagynak kell lennie, hogy ne legyen túlzsúfolt, ugyanakkor elég kicsinek ahhoz, hogy az összebújt kisnyulak melegítsék egymást. Nagyméretü elletőládában kihülhetnek, elpusztulhatnak a fészekből kimászó kisnyulak.

- Az elletőládát, illetve a fészektálcát a várható fialás előtt legalább három nappal kell az állatok számára biztosítani, hogy az anyanyúlnak elég ideje maradjon a jó minőségü fészek elkészítésére.

Megjegyzés: A fészekkészítési viselkedést (fialóüreg kiásása, alomanyag behordása, szőr tépése a testről) hormonok szabályozzák (González-Mariscal és mtsai, 1994, 1996; Negatu és McNitt, 2002). Az anyanyulak 2-3 nappal a fialás elött kezdik el behordani az alomanyagot, vagyis építeni a fészket (Zarrow és mtsai, 1963; González-Mariscal és mtsai, 1996).

- Az anyanyulaknak a fészeképítéshez megfelelő alomanyagot (pl. faforgácsot, szénát, szalmát) kell biztosítani.

Megjegyzés: A csupaszon, gyenge höszabályozással született kisnyulak megfelelően kialakított és szőrrel takart fészekben, összebújva, egymást melegítve - a néhány perces szopást kivéve - alszanak. Az üregi anyanyulak száraz füvet és más anyagokat gyújtenek, és ezekből készítik el a fészket (Hudson és mtsai, 2000). Megfeleló fészek hiányában az üregi és a házinyulaknál is megemelkedik a szopósnyulak elhullása (Canali és mtsai, 1991). A nyúltelepeken leggyakrabban faforgácsot, szalmát 
vagy szénát használnak fészekanyagnak (Blumetto és mtsai, 2010). Bár szabad választásnál a nyulak nem részesítik elönyben a faforgácsot (Farkas és mtsai, 2017), de a gyakorlatban jól bevált.

- Zárható búvónyílású elletőláda javasolt.

Megjegyzés: A nyúltelepeken korábban fóként szabad-, az utóbbi években napi egyszeri szoptatást végeznek. A két szoptatási mód összehasonlításakor ellentmondó eredményeket kaptak (Pizzi és Crimella, 1985; Costantini és mtsai, 1986; Coureaud és mtsai, 1998; Szendrő és mtsai, 1999). Mivel a kisnyulak életük első 12 napjában csak szopnak és alszanak, ezért, a megijedt, elletôládába ugró anyanyúl megzavarhatja, szétszórhatja, megsebesítheti, akár agyon is taposhatja őket, ezért az egyszeri szoptatás állatjólléti oldalról elónyös lehet (Szendrő és mtsai, 1999). A napi egyszeri szoptatás nem természetellenes, mert az üregi és a házinyúl is leggyakrabban 24 óránként, egyszer szoptatja kicsinyeit, aminek időtartama 3-4 perc (Zarrow és mtsai, 1965; Hudson és Distel, 1982; Hoy és mtsai, 2000; Hoy és Selzer, 2002). Az üregi nyulaknál megfigyelték, hogy fialás és minden szoptatási alkalom után az anyanyúl füvel, levelekkel és földdel tömi be az üreg bejáratát, hogy elrejtve azt csökkentse a ragadozók kártételét (Zarrow és mtsai 1965; Lloyd és McCowan, 1968).

- Naponta ellenőrizni kell az elletőládát és benne a szopósnyulakat.

Megjegyzés: Fialáskor el kell távolítani a halva született és az életképtelen kisnyulakat. Alom-kiegyenlítést célszerü elvégezni úgy, hogy az elöször fialó anyanyulak alatt legfeljebb 8, az idősebbeknél 10, lehetőleg azonos súlyú kisnyúl maradjon. Ezzel az elhullás mellett az almon belüli súly szóródását is csökkenteni lehet (Bautista és mtsai, 2008, 2015). Ha az anyanyúl nem tép elég szôrt, a testéröl kitépett szőrrel kell az almot betakarni.

- Fémrácspadozat esetén, a talpfekély kialakulásának megelőzése céljából, legalább $25 \times 40 \mathrm{~cm}$ nagyságú, perforált műanyag pihenőlap szükséges. Hasonló célt szolgál a műanyag rácsból készült polc.

Megjegyzés: Az anyanyulaknál - mivel viszonylag nagy a testsúlyuk és hosszú ideig termelnek - fémrácspadozaton gyakran alakulhat ki a talpfekély enyhébb vagy súlyosabb formája (De Jong és mtsai, 2008; Rosell és de la Fuente, 2009). Pihenólap behelyezése esetén csökken a talpfekély elöfordulási gyakorisága és annak súlyossága is (De Jong és mtsai, 2008; Rosell és de la Fuente, 2009, Rommers és De Jong, 2011; Mikó és mtsai, 2014). Hasonló pozitív eredmény érhető el, ha a ketrecben múanyagrács-polc található (Mikó és mtsai, 2014).

\section{A baknyulak tartásának minimális követelményei}

- A hímivarú tenyésznövendék-nyulakat 10 hetes kortól - agresszió, verekedés, sérülés és egymás kasztrálásának megelőzése céljából - egyedileg kell elhelyezni. 
- A baknyulaknak legalább 50x64 cm alapterületủ és 40 cm magas ketrec javasolt.

- Fémrácspadozat esetén, a talpfekély kialakulásának megelőzése céljából, legalább 25×40 cm nagyságú perforált műanyag pihenőlapot kell behelyezni, de a műanyagrács-padozat alkalmazása megfelelőbb.

\section{A növendéknyulak tartásának minimális követelményei}

- Az állatok megfelelő ellenőrzése érdekében a növendéknyulakat legfeljebb háromszintes ketrecsorban szabad elhelyezni.

- Nem engedhető meg a hízónyulak egyedi tartása, kivéve az agresszív és a beteg egyedeket.

Megjegyzés: Bár egyedi elhelyezés esetén érhetô el a legjobb termelés (Maertens és De Groote, 1984; Xiccato és mtsai, 1999, 2013), de ebben korlátozott a szociális kapcsolat, és emiatt a stressz élettani tünetei (Held és mtsai, 1995; Chu és mtsai, 2004), unatkozás, bizonyos sztereotip viselkedés, mint a rács nyaldosása vagy rágása, figyelhető meg (Podberscek és mtsai, 1991).

- A hizlaló ketrecbe legalább 2-3 növendéknyulat kell tenni. Több nyúl esetén nem javasolt, ha fülkénként egy alomnál (8-10 nyúlnál) több egyedet nevelnek együtt.

Megjegyzés: Minél nagyobb a csoport létszáma, annál gyengébb termelés várható (Szendrő és Dalle Zotte, 2011). Legnagyobb probléma, hogy minél nagyobb a csoport, annál nagyobb az esély arra, hogy a fülkében agresszív egyed is legyen, ezért a csoportnagyság növekedésével párhuzamosan gyakoribb a sérült egyedek elöfordulása (Bigler és Oester, 1996; Szendrő és mtsai, 2009). A gyakoribb verekedés miatti krónikus stressz a takarmányfogyasztás és az ellenállóképesség csökkenését, a megbetegedések gyakoribb fellépését okozhatja. Rágófa behelyezésével, különösen, ha puhafából készül, csökkenthetô az agresszivitás és a sérülések elöfordulása.

- A növendéknyulaknál legfeljebb 16 nyúl/m² a megengedhető telepítési sűrűség, ami a hizlalás végén 40-45 $\mathrm{kg}$ nyúl $/ \mathrm{m}^{2}$-nek felel meg.

Megjegyzés: Számos kísérlet eredménye igazolja, hogy 16-17 nyúl/m² telepítési sürűség felett romlik a termelés (Szendrő és Dalle Zotte, 2011). Maertens és De Groote (1985), valamint Aubret és Duperray (1992) igazolták, hogy az $1 \mathrm{~m}^{2}$-re esố nyúl súlya pontosabban meghatározza az ideális telepítési sürüséget, mint az egyedek száma. Bár többen ennél kisebb telepítési sürüséget ajánlanak, de ennek előnyét még nem bizonyították. 
- A hízónyulaknak legalább 30-35 cm legyen a ketrec vagy fülke magassága.

Megjegyzés: Többen úgy gondolják, hogy a nyulaknál fontos a hátulsó lábakra állás, a felegyenesedő figyelő testtartás. Az üregi nyulaknál ez életbevágó, mert az álló testhelyzet (upright alert position) segíti a ragadozó időben történő észrevételét (Gunn és Morton, 1995). Az istállóban - ragadozó híján - nincs gyakorlati jelentösége ennek a viselkedésnek. Nyitott tetejü ketrecben a nyulak idejük 0,7\%-át töltötték ebben a testhelyzetben (Martrenchar és mtsai, 2001), Finzi (2005; cit. Princz és mtsai, 2008b) még ennél is kisebb gyakoriságot figyelt meg. Amikor a növendéknyulak szabadon választhattak, lengőajtókon keresztül mozoghattak a 20, 30, 40 cm magas és a felül nyitott ketrecek között, fele annyi nyúl tartózkodott a felül nyitottban, mint bármelyik más ketrecben (Princz és mtsai, 2008c). Amikor polc volt a fülkében a legtöbb nyúl a "védelmet nyújtó" polc alatt vagy a polcon tartózkodott és nem a tetô nélküli részen (Szendrő és mtsai, 2011). A $20 \mathrm{~cm}$ magas fülke viszont már túl alacsony, mert ebben gyakoribb volt az agresszív viselkedés és a sérülés. Ezek a megfigyelések összhangban vannak az üreginyulak viselkedésével. Azok is a felülról takarást, védelmet nyújtó bokros területet részesítik előnyben, pihenésre és alvásra pedig az igen szúk üregrendszert választják (Villafuerte és Moreno, 1997; Lombardini és mtsai, 2003). A fentiek alapján megalapozott a 30-35 cm magas ketrec ajánlása.

- Nem javasolt a növendéknyulak mélyalmon történő tartása.

Megjegyzés: Szabad helyválasztásos kísérletekben - a hőmérséklettől és a telepítési sürüségtôl függetlenül - a növendéknyulak gyakrabban tartózkodtak müanyagvagy fémrácspadozaton, mint mélyalmon (Morisse és mtsai, 1999; Bessei és mtsai, 2001; Orova és mtsai, 2004; Gerencsér és mtsai, 2014). A mélyalom kényelmesnek tünik, de a bundában levő nyulak nem tudnak megszabadulni az emésztés során keletkező hőtoól, ezért szívesebben választják a kevésbé kényelmes, de jó hővezető, hüvösebb padozatot (Bessei és mtsai, 2001). A nyulak esznek a bélsárral és vizelettel kevert alomanyagból (Maertens és Van Oeckel, 2001; Jekkel és mtsai, 2008), ezért kevesebb takarmányt fogyasztanak (Kustos és mtsai, 2003), csökken a súlygyarapodásuk és gyakoribb az emésztöszervi megbetegedés és az elhullás előfordulása, mint fémrács padozaton (Dal Bosco és mtsai, 2000, 2002; Lambertini és mtsai, 2001; Gerencsér és mtsai, 2014).

- A fémrács- és a műanyagrács-padozat egyaránt elfogadott.

Megjegyzés: Nincs vagy elhanyagolható a különbség a különböző padozatokon (müanyag rács, fémrács, léc) tartott nyulak termelésében és viselkedésében (Petersen és mtsai, 2000; Trocino és mtsai, 2008; Princz és mtsai, 2008b, 2009). A fém- és müanyagrács nagy előnye, hogy a trágya lehullik, nem érintkeznek vele az állatok, ezért csökken a kokcidiózis elófodulása, és szabad helyválasztás esetén gyakrabban tartózkodnak rajtuk a nyulak, mint mélyalmon (Morisse és mtsai, 1999; Bessei és mtsai, 2001; De Jong és mtsai, 2008). Melegben és idősebb korban a növendéknyu- 
lak még a müanyagrácsnál is gyakrabban választják a fémrácsot, mert jobb hővezető és hidegebb, emiatt a nyulak könnyebben szabadulnak meg a höterheléstôl (Gerencsér és mtsai, 2014). Fontos azonban a lyuk és a padozat anyagának aránya. Ha a felülethez képest kevés a lyuk, felboltozódik a trágya és nő a fertőzés esélye (Masthoff és mtsai, 2016). Fémrács esetében legalább $2 \mathrm{~mm}$ átmérôjü huzalt és 55 x 20 mm-es rácsközt ajánlanak.

- Csoportos tartásban tíz nyúl számára legalább 10 cm széles etető ajánlott. Nagyobb létszám esetén a nyulak számával arányosan növelni kell az etető méretét.

Megjegyzés: 13 nyúl számára 10,20, 30 vagy $40 \mathrm{~cm}$ széles etetőt tettek a fülkébe (Orova, 2008, személyes közlés). 10 cm-es etető esetében sem találtak különbséget termelésben és agresszív viselkedésben. Vagyis ad libitum takarmányozásnál tíz nyúl számára elegendő a $10 \mathrm{~cm}$ széles etető.

- Csoportos tartásban annyi itató legyen a fülkében, hogy a nyulak egymás zavarása, versengés nélkül tudjanak inni. Tíz nyúl számára legalább két súlyszelepes itató szükséges.

Megjegyzés: Orova (2008, személyes közlés) szerint 13 nyúl számára elég egy itatószelep. Biztonság kedvéért jobb, ha két itató van egy ketrecben.

\section{ZÁRÓ GONDOLATOK}

A házinyulak nagyüzemi tartásának minimális követelményeit nem érzelmi alapon, hanem kutatási eredményekre támaszkodva foglaltuk össze. A bevezetésben olvasható, hogy magyar vezetéssel vagy közreműködéssel eddig már több összefoglaló mű született. Ezzel a közleménnyel egyidőben jelenik meg az anyanyulak tartásával kapcsolatban a legújabb kutatási eredményeket összefoglaló cikk, de hamarosan elkészül a növendéknyulakkal foglalkozó írásunk is, angol nyelven. Jelen cikkel hármas célunk teljesülhet. Egyrészt a készülő állatvédelmi szabályozásról szóló FM-rendelet megalkotását szeretnénk segíteni, másrészt az angol nyelvü összefoglalóból a világon bárki láthatja, hogy Magyarországon milyen előírások vannak, illetve várhatók a házinyulakkal kapcsolatban. Harmadrészt, a követelmények mellett ezek indoklását bárki elolvashatja magyarul. Jó lenne, ha ezzel az érdekeltek jobban tudnák érvényesíteni - a nyulak jóllétének szem előtt tartásával - a magyar érdekeket.

A világon kevés kutató foglalkozik a nyulak viselkedésével és jóllétével. Erre vezethető vissza, hogy több olyan kérdés van, amit alaposan vizsgálni kellene. Jóllehet számos esetben egyértelmű következtetés vonható le a kutatási eredményekből, ennek ellenére még mindig van támogatója a növendéknyulak mélyalmos vagy az anyanyulak csoportos tartásának. Pedig ezek több ponton 
ellentétesek az állatok öt szabadságjogával (Farm Animal Welfare Council, 1992).

Úgy tünik, hogy az EU is foglalkozik a nyulak tartási követelményeinek megfogalmazásával és elfogadásával. Több állatfaj példáját látva nem lehetünk biztosak abban, hogy az összes előírás a nyulak jóllétét fogja szolgálni, mert az állatvédők mindent elkövetnek, hogy elképzelésükből minél több kerüljön be a törvénybe. Sajnos a kutatási eredmények sokszor még a legérintettebb termelőkig sem jutnak el, és érdekeiket sem tudják megfelelően érvényesíteni. A kutatóknak pedig nem feladatuk, hogy az EU-törvényhozókig hallassák szavukat, ők tudományos és szakmai cikkekben, nemzetközi és hazai konferenciákon ismertetik eredményeiket. Nemcsak a nyúltenyésztóknek, hanem minden gazdasági állatfaj tenyésztőjének szüksége lenne az összefogásra, valamint arra, hogy a helyes állattartást olyan modern hírközlő eszközök használatával mutassák be, mint a fiatalok által általánosan használt YouTube, az Instagram, vagy a Facebook.

\section{KÖSZÖNETNYILVÁNÍTÁS}

Köszönöm a WRSA Magyar Tagozata támogatását és a cikk elkészítéséhez nyújtott segítségét. A publikáció elkészítését a EFOP-3.6.3-VEKOP-16-201700008 számú projekt támogatta. A projekt az Európai Unió támogatásával, az Európai Szociális Alap társfinanszírozásával valósult meg.

\section{IRODALOM}

Andrist C.A., Bigler L.M., Würbel H., Roth B.A. 2012. Effects of group stability on aggression, stress and injuries in breeding rabbits. Appl. Anim. Behav. Sci., 142, 182-188. DOI: 10.1016/j.applanim.2012.10.017

Andrist C.A., van den Borne B.H.P., Bigler L.M., Buchwalder T., Roth B.A. 2013. Epidemiologic survey in Swiss group-housed breeding rabbits: Extent of lesions and potential risk factors. Prev. Vet. Med., 108, 218-224. DOI: 10.1016/j.prevetmed.2012.07.015

Andrist C.A., Bigler L.M., Würbel H., Roth B.A. 2014. Masking odour when regrouping rabbit does: Effect on aggression, stress and lesions. Livest. Sci., 170, 150-157. DOI: 10.1016/j.livsci.2014.10.017

Aubret J.M., Duperray J. 1992. Effect of cage density on the performance and health of growing rabbit. J. Appl. Rabbit Res., 15, 660-665.

Bautista A., García-Torres E., Martínez-Gómez M., Hudson R. 2008. Do newborn domestic rabbits Oryctolagus cuniculus compete for thermally advantageous positions in the litter huddle? Behav. Ecol. Sociobiol. 62, 331-339. DOI: 10.1007/s00265-007-0420-4

Bautista A., Zepeda J.A., Reyes-Meza V., Martínez-Gómez M., Rödel H.G., Hudson R. 2015. Contribution of within-litter interactions to individual differences in early postnatal growth in the domestic rabbit. Anim. Behav., 108, 145-153. DOI: 10.1016/j.anbehav.2015.07.028 
Bessei W., Tinz J., Reiter K., 2001. Die Präferenz von Mastkaninchen für Kunststoffgitter und Tiefstreu bei unterschiedlichen Temperaturen. Proc. 12th Arbeitstagung über Haltung und Krankheiten der Kaninchen, Pelztiere und Heimtiere, Celle. Germany, 133-140.

Bigler L., Oester H. 1996. Group housing for male rabbits. Proc. 6th World Rabbit Congress, Toulouse, France, Vol. 2, 411-415.

Blumetto O., Olivas I., Torres A.G., Villagrá A. 2010. Use of straw and wood shavings as nest material in primiparous does. World Rabbit Sci. 18, 237-242. DOI: 10.4995/wrs.2010.776

Brewer N.R., Cruise L.J. 1994. Physiology. In: Manning P.J., Ringler D.H., Newcomer C.E. (Eds.), The Biology of the Laboratory Rabbit. Academic Press, New York, 63-70.

Canali E., Ferrante V., Todeschini R., Verga M., Carenzi C. 1991. Rabbit nest construction and its relationship with litter development. Appl. Anim. Behav. Sci., 31, 259-266. DOI: 10.1016/01681591(91)90010-U

Cervera C., Fernández Carmona J. 2010. Nutrition and the climatic environment. In: de Blas C. and Wiseman J. (eds) Nutrition of the Rabbit, 2nd Edition, CAB International, Oxfordshire, 267-284.

Chu L., Garner J.P., Mench J.A. 2004. A behavioral comparison of New Zealand White rabbits (Oryctolagus cuniculus) housed individually or in pairs in conventional laboratory cages. Appl. Anim. Behav. Sci., 85, 121-139. D0I: 10.1016/j.applanim.2003.09.011

Costantini F., Panella F., Castellini C. 1986. Management of rabbit breeding. Rivista di Coniglicoltura, 23, 44-46.

Council Directive 98/58/EC of 20 July 1998 concerning the protection of animals kept for farming purposes (OJ L 221, 8.8.1998, p. 23).

Council Directive 1999/74/EC of 19 July 1999 laying down minimum standards for the protection of laying hens (OJ L 203, 3.8.1999, p. 53).

Council Directive 2007/43/EC of 28 June 2007 laying down minimum rules for the protection of chickens kept for meat production (OJ L 182, 12.7.2007, p. 19).

Council Directive 2008/119/EC of 18 December 2008 laying down minimum standards for the protection of calves (OJ L 10, 11.1.2009, p. 7).

Council Directive 2008/120/EC of 18 December 2008 laying down minimum standards for the protection of pigs (OJ L 47, 18.2.2009, p. 5).

Coureaud G., Schaal B., Orgeur P., Coudert P. 1998. Le controle de l'acces au nid chez la lapine: conséquences sur la mortalité des lapereaux. Proc. 7émes Journ. Rech. Cunicole, France, Lyon, 245249.

Cowan, D.P.,1987. Groupliving in the European rabbit (Oryctolagus cuniculus): mutual benefit or resource localization? J. Anim. Ecol., 5, 779-795. DOI: $\underline{10.2307 / 4948}$

Dal Bosco A., Castellini C., Bernardini M. 2000. Productive performance and carcass and meat characteristics of cage- or pen-raised rabbits. World Rabbit Sci. 8, Suppl. A, 579-583.

Dal Bosco A., Castellini C., Mugnai D, 2002. Rearing rabbits on a wire net floor or straw litter: behaviour, growth and meat quality traits. Livest. Prod. Sci., 75, 149-156. DOI: 10.1016/S03016226(01)00307-4

De Jong I.C., Reimert H., Rommers J.M.. 2008. Effect of floor type on footpad injuries in does: a pilot study. Proc. 9th World Rabbit Congress, Verona, Italy, 1171-1175.

Díez C., Pérez J.A., Prieto R., Alonso M.E., Olmedo J.A. 2005. Activity patterns of wild rabbit (Oryctolagus Cuniculus, L.1758), under semi-freedom conditions, during autumn and winter. Wildl. Biol. Pract., 1, 41-46. DOI: $10.2461 / w b p .2005 .1 .6$

Ebensperger L.A., Wallem P.K. 2002. Grouping increased the ability of the social rodent, Octodon degus, to detect predators when using exposed microbhabitats. Oikos, 98, 491-497. DOI: 10.1034/j.1600$\underline{0706.2002 .980313 . x}$ 
EFSA, 2005. The impact of the current housing and husbandry systems on the health and welfare of farmed domestic rabbits. The EFSA Journal, 267, 1-140.

Farkas T. P., Szendrő Zs., Matics Zs., Radnai I., Nagy I., Gerencsér Zs. 2017. Preference of rabbit does among different nest materials. World Rabbit Sci., 26, 81-90. DOI: $\underline{10.4995 / w r s .2018 .7373}$

Farm Animal Welfare Council (FAWC) 1992. FAWC updates the five freedoms. Vet. Rec., 131, 357

Gerencsér Zs., Szendrő K., Szendrő Zs., Odermatt M., Radnai I., Nagy I., Dal Bosco A., Matics Zs. 2014. Effect of floor type on behavior and productive performance of growing rabbits. Livest. Sci., 165, 114-119. DOI: 10.1016/j.livsci.2014.04.022

González-Mariscal, G., Rosenblatt, J. S. 1996. Maternal behavior in rabbits: A historical and multidisciplinary perspective. Adv. Study Behav., 25, 333-359. DOI: $\underline{10.1016 / S 0065-}$ $\underline{3454(08) 60337-X}$

González-Mariscal G., Díaz-Sánchez V., Melo A.I., Beyer C., Rosenblatt J.S. 1994. Maternal behavior in New Zealand white rabbits: Quantification of somatic events, motor patterns, and steroid plasma levels. Physiol. Behav., 55, 1081-1089. DOI: 10.1016/0031-9384(94)90391-3

González-Mariscal G., Melo I.A., Jimenez P., Beyer C., Rosenblatt S.J. 1996. Estradiol, progesterone, and prolactin regulate maternal nest-building in rabbits. J. Neuroendocrinol., 8, 901-907. DOI: 10.1111/j.1365-2826.1996.tb00818.x

González-Mariscal G., Burt A.S., Nowak R. 2017. Behavioral and neuroendocrine indicators of well-being in farm and laboratory mammals. In: Pfaff D.W., Joëls M. (eds): Hormones, Brain and Behavior (Third Edition). Elsevier Inc., Amsterdam, 453-485.

Graf S., Bigler L.M., Failing K., Würbel H., Buchwalder T. 2011. Regrouping rabbit does in a familiar or novel pen: Effects on agonistic behaviour, injuries and core body temperature. Appl. Anim. Behav. Sci., 135, 121-127. DOI: 10.1016/j.applanim.2011.10.009

Gunn D., Morton D.B. 1995. Inventory of the behaviour of New Zealand White rabbits in laboratory cages. Appl. Anim. Behav. Sci., 45, 277-292. DOI: 10.1016/0168-1591(95)00627-5

Hayward J., Lisson P. 1978. Carbon dioxide tolerance of rabbits and its relation to burrow fumigation. Wildlife Res., 5, 253-261. DOI: $\underline{10.1071 / W R 9780253}$

Held S.D.E., Turner R.J., Wootton R.J. 1995. Choice of laboratory rabbits for individual or group-housing. Appl. Anim. Behav. Sci., 46, 81-91. DOI: 10.1016/0168-1591(95)00632-X

Holst D. von, Hutzelmeyer H., Kaetze P., Khashei M., Schönheiter R. 1999. Social rank, stress, fitness and life expectancy in wild rabbits. Naturwissenschaften, 86, 388-393. DOI: $10.1007 / \mathrm{s} 001140050638$

Holst D. von, Hutzelmeyer H., Kaetze, P., Khashei M., Rödel H.G., Schrutka H. 2002. Social rank, fecundity and life time reproductive success in wild European rabbits (Oryctolagus cuniculus). Behav. Ecol. Sociobiol., 51, 245-254. DOI: 10.1007/s00265-001-0427-1

Hoy St., Lange K. 1997. Ergebnisse kontinuierlicher Ammoniak- und Kohlendioxidmessungen in der Kaninchenhaltung. Proc. 10. Arbeitstagung über Haltung und Krankheiten der Kaninchen, Pelztiere und Heimtiere. Celle, Germany, 298-303.

Hoy St., Selzer D. 2002. Frequency and time of nursing in wild and domestic rabbits housed outdoors in free range. World Rabbit Sci., 10, 77-84. DOI: 10.4995/wrs.2002.479

Hoy St., Seitz K., Selzer D., Schüddemage M. 2000. Nursing behaviour of domesticated and wild rabbit does under different keeping conditions. Proc. $7^{\text {th }}$ World Rabbit Congress, Valencia, Spain, 537543.

Hoy St., Matics Zs. 2016. Alternative housing systems for rabbit does. Proc. 11th World Rabbit Congress, Qingdao, China, 637-651.

Hoy St. ed. 2006. Housing of rabbits in conformity with animal welfare and protection criteria. In: Maertens L., Coudert P. Recent advances in rabbit sciences. ILVO, Melle, Belgium, 69-130. 
Hudson R., Distel H. 1982. The pattern of behaviour of rabbit pups in the nest. Behaviour, 79, 255-271. DOI: $10.1163 / 156853982 X 00292$

Hudson R., Schaal B., Martínez-Gómez M., Distel H. 2000. Mother-young relations in the European rabbit: physiological and behavioural locks and keys. World Rabbit Sci., 8, 85-90. DOI: $10.4995 /$ wrs.2000.424

Hull D, Hull J, Vinter J. 1986. The preferred environmental temperature of newborn rabbits. Biol. Neonate, 50, 323-330. DOI: $10.1159 / 000242616$

Jekkel G., Milisits G., Biró-Németh E., Radnai I., Matics Zs., Princz Z., Gerencsér Zs. 2008. Comparison on the slaughter characteristics of growing rabbits reared on wire net or combined (wire net/straw) floor. Proc. 9th World Rabbit Congress, Verona, Italy, 1365-1369.

König, B. 1997. Cooperative care of young in mammals. Naturwissenschaften, 84, 95-104. DOI: $\underline{10.1007 / s 001140050356}$

Kustos K., Tóbiás G., Kovács D., Eiben Cs., Szendrő Zs. 2003. A telepítési sűrűség, a padozat és a takarmányozás hatása a növendéknyulak termelésére. 15. Nyúltenyésztési Tudományos Nap, Kaposvár, 123-128.

Lambertini L., Vignola G., Zagnini G. 2001. Alternative pen housing system for fattening rabbits: Effect of density and litter. World Rabbit Sci., 9, 141-147. DOI: 10.4995/wrs.2001.457

Lebas F., Coudert P., de Rochambeau H., Thébault R.G. 1997. The Rabbit. Husbandry, health and production. FAO Animal Production and Health. Rome, Series No 21.

Lloyd H.G., McCowan D. 1968. Some observations on the breeding burrows of the wild rabbit Oryctolagus cuniculus on the island of Skokholm. J. Zool. (London), 156, 540-549. DOI: 10.1111/j.1469-7998.1968.tb04376.X

Lombardini L., Fernández N., Moreno S., Villafuert R. 2003. Habitat-related differences in rabbit (Oryctolagus cuniculus) abundance, distribution, and activity. J. Mammal., 84, 26-36. DOI: 10.1644/1545-1542(2003)084<0026:HRDIRO>2.0.CO;2

Lukefahr S.D., Ruiz-Feria C.A. 2003. Rabbit growth performance in a subtropical and semi-arid environment: effects of fur clipping, ear length, and body temperature. Livest. Res. Rural Develop., $15,1-10$.

Maertens L., Buijs S. 2015. Production performances of semi-group housed rabbit does. Proc. 19th International Symposium on Housing and Diseases of Rabbits, Furproviding Animals and Pet Animals, Celle, Germany, 22-31.

Maertens L., De Groote G. 1984. Influence of the number of fryer rabbits per cage on their performance. J. Appl. Rabbit Res., 7, 151-155.

Maertens, L., De Groote, G., 1985. L'influence de la densité d'occupation sur les résultats d'engraissement des lapins de chair. Rev. Agric., 38, 463-471.

Maertens L., Van Oeckel M.J. 2001. Effet du logement en cage on en parc et de son enrichment sur les performances et la couleur de la viande des lapins. Proc. 9émes Journ. Rech. Cunicole, Paris, France, 31-34.

Maertens L., Rommers J., Jacquet M. 2011. Le logement des lapins en parcs, une alternative pour les cages classiques dans un système "duo"? Proc. 14èmes Journ. Rech. Cunicole, Le Mans, France, 8588.

Martrenchar A., Boilletot E., Cotte J.P., Morisse J.P. 2001. Wire-floor pens as an alternative to metallic cages in fattening rabbits: influence on some welfare traits. Anim. Welfare, 10, 153-161.

Masthoff T., Lang C., Hoy St. 2016. Effect of group size on fattening performance and of various types of slatted floor on dirtiness and occurrence of pododermatitis in growing rabbits. Proc. 11th World Rabbit Congress, Qingdao, China, 715-718. 
Mikó A., Matics Zs., Gerencsér Zs., Odermatt M., Radnai I., Nagy I., Szendrő K., Szendrő Zs. 2014. Performance and welfare of rabbit does in various caging systems. Animal, 8, 1146-1152. DOI: $\underline{10.1017 / s 1751731114001244}$

Mirabito L., Buthon L., Cialdi G., Galliot P., Souchet C. 1999. Effect du logement des lapines en cages rehausse' es avec plat-forme: Premiers re' sultats. Proc. 8émes Journ. Rech. Cunicole, Paris, France, 67-70.

Mirabito L., Galliot P., Souchet C. 2004. Effet de la surface disponible et de l'ame'nagement des cages sur les performances zootechniques et le comportement des lapines et des jeunes. Proc. Journ. Nationale de l'élevage du lapin de chair, 40-52.

Mirabito L., Galliot P., Souchet C., Dumont F., Thomeret F. 2005. Logement collectif des lapines reproductrices: Conséquences zootechniques. Proc. 11émes Journ. Rech. Cunicole, Paris, France, 53-56.

Morisse J.P., Boilletot E., Martrenchar, A. 1999. Preference testing in intensively kept meat production rabbits for straw on wire grid floor. Appl. Anim. Behav. Sci., 64, 71-80. DOI: 10.1016/S0168$\underline{1591(99) 00023-4}$

Negatu Z., McNitt J. I. 2002. Hormone profiles and nest-building behavior during the periparturient period in rabbit does. Anim. Reprod. Sci., 72, 125-135. DOI: 10.1016/S0378-4320(02)00070-2

Orova Z. 2008. Személyes közlés

Orova Z., Szendrő Zs., Matics Zs., Radnai I., Biró-Németh E., 2004. Free choice of growing rabbits between deep litter and wire net floor in pens. Proc. 8th World Rabbit Congress, Puebla City, Mexico, 1263-1265.

Pizzi F., Crimella C. 1985. Allattamento controlato in coniglicultura. Influenze sugli asorescimenti ed incidi conversione alimentara dallo svezzamento all eta di macellezione. Atti-della-Societa Italianadelle-Scienze Veterinarie, 39, 467-470.

Podberscek A.L., Blackshaw J.K., Beattie A.W. 1991. The behaviour of group penned and individually caged laboratory rabbits. Appl. Anim. Behav. Sci., 28, 353-363. D0I: 10.1016/0168-1591(91)90167$\underline{V}$

Princz Z., Orova Z., Nagy I., Jordan D., Štuhec I, Luzi F., Verga M., Szendrő Zs. 2007. Application of gnawing sticks in rabbit housing. World Rabbit Sci., 15, 29-36. DOI: 10.4995/wrs.2007.607

Princz Z., Nagy I., Biró-Németh E., Matics Zs., Szendrő Zs. 2008a. Effect of gnawing sticks on the welfare of growing rabbits. Proc. 9th World Rabbit Congress, Verona, Italy, 1221-1224.

Princz Z., Dalle Zotte A., Radnai I., Biró-Németh E., Matics Zs., Gerencsér Zs., Nagy I., Szendrő Zs. 2008b. Behaviour of growing rabbits under various housing conditions. Appl. Anim. Behav. Sci., 111, 342356. DOI: 10.1016/j.applanim.2007.06.013

Princz Z., Radnai I., Biróné Németh E., Matics Zs., Gerencsér Zs., Nagy I., Szendrő Zs. 2008c. Effect of cage height on the welfare of growing rabbits. Appl. Anim. Behav. Sci., 114, 284-295. DOI: 10.1016/j.applanim.2008.01.006

Princz Z., Dalle Zotte A., Metzger Sz., Radnai I., Biró-Németh E., Orova Z., Szendrő Zs. 2009. Response of fattening rabbits reared under different housing conditions. 1. Live performance and health status. Livest. Sci., 121, 86-91. DOI: 10.1016/j.livsci.2008.05.018

Prud'hon M., Chérubin M., Goussupoulos J., Charles Y. 1975. Évolution, aucours de la croissance, des caractéristiques de la consommation d'aliments solide et liquide du lapin domestique nourri ad libitum. Ann. Zootech., 24, 289-298.

Rommers J.M., Jong de I.C. 2011. Technical note: Plastic mats prevent footpad injuries in rabbit doe. World Rabbit Sci., 19, 233-237. DOI: 10.4995/wrs.2011.868

Rommers J.M., Meijerhof R. 1998. La dimensions de la cage influence-t-elle la productivitè et la bienèntre des lapins. Cuniculture, 25, 67-72. 
Rommers J.M., Boiti C., de Jong I., Brecchia G. 2006. Performance and behaviour of rabbit does in a group-housing system with natural mating or artificial insemination. Reprod. Nutr. Dev., 46, 677687. DOI: $\underline{10.1051 / r n d: 2006038}$

Rommers J.M., Gunnink H., Klop A., de Jong I.C. 2011. Dynamics in aggressive behaviour of rabbit does in a group-housing system: a descriptive study. Proc. 17th International Symposium on Housing and Diseases of Rabbits, Fur Providing Animals and Pet Animals, Celle, Germany, 75-85.

Rommers J.M., Gunnink H., de Jong I.C. 2013. Effect of different types of places on aggression among does in a group-housing system: A pilot study. Proc. 18th International Symposium on Housing and Diseases of Rabbits, Fur Providing Animals and Pet Animals, Celle, Germany, pp. 59-68.

Rosell J.M., de la Fuente L.F. 2009. Effect of footrests on the incidence of ulcerative pododermatitis in domestic rabbit does. Anim. Welfare, 18, 199-204.

Rödel H.G., Bora A., Kaiser J., Kaetzke P., Khaschei M., von Holst D. 2004. Density-dependent reproduction in the European rabbit: a consequence of individual response and age-dependent reproductive performance. Oikos, 104, 529-539. DOI: 10.1111/j.0030-1299.2004.12691.X

Rödel G.H., Starkloff A., Bautista A., Friderich A.C., von Holst D. 2008. Infanticide and maternal offspring defence in European wild rabbits under natural breeding condition. Ethology, 114, 22-31. DOI: $\underline{10.1111 / j .1439-0310.2007 .01447 . x}$

Schlolaut W. 1998. Das große Buch vom Kaninchen. DLGVerlag, Frankfurt am Main.

Southern H.N. 1948. Sexual and aggressive behaviour of the wild rabbit. Behaviour, 1, 173-194. DOI: $10.1163 / 156853948 \times 00092$

Szendrő Zs., Dalle Zotte A. 2011. Effect of housing conditions on production and behaviour of growing meat rabbits: A review. Livest. Sci., 137, 296-303. DOI: 10.1016/j.livsci.2010.11.012

Szendrő Zs., McNitt I.J. 2012. Housing of rabbit does: Group and individual systems: A review. Livest. Sci., 150, 1-10. DOI: 10.1016/j.livsci.2012.09.017

Szendrő Zs., Gyarmati T., Lévai A., Radnai I., Biróné Németh E., Milisits G. 1999. Comparison of oncedaily, free and combined forms of suckling in rabbits. Acta Agr. Kapos., 3, 155-163.

Szendrő Zs., Princz Z., Romvári R., Locsmándi L., Szabó A., Bázár Gy., Radnai I., Biró-Németh E., Matics Zs., Nagy I. 2009. Effect of group size and stocking density on productive, carcass and meat quality traits and aggression of growing rabbits. World Rabbit Sci., 17, 153-162. DOI: $\underline{10.4995 / w r s .2009 .655}$

Szendrő Zs., Matics Zs., Odermatt M., Gerencsér Zs., Nagy I., Szendrő K., Dalle Zotte A. 2011. Use of different areas of pen by growing rabbits depending on the elevated platforms' floor-type. Animal, 6, 650-655. DOI: $10.1017 / S 1751731111001819$

Szendrő Zs., Mikó A., Odermatt M., Gerencsér Zs., Radnai I., Dezséry B., Garai É., Nagy I., Szendrő K., Matics Zs. 2013. Comparison of performance and welfare of single-caged and group-housed rabbit does. Animal, 7, 463-468. DOI: $\underline{10.1017 / s 1751731112001760}$

Szendrő Zs., McNitt I.J., Matics Zs., Mikó A., Gerencsér Zs. 2016. Alternative and enriched housing systems for breeding does: A review. World Rabbit Sci., 24, 1-14. DOI: 10.4995/wrs.2016.3801

Szendrő Zs., Trocino A., Hoy St., Xiccato G., Villagrá A., Szendrő K., Maertens L. 2019. A review of recent research outcomes about the housing of farmed domestic rabbits: Reproducing does. Wold Rabbit Sci., 27, 1-14. DOI: 10.4995/wrs.2019.10599

Trocino A., Xiccato G. 2006. Animal welfare in reared rabbits: A review with emphasis on housing systems. World Rabbit Sci., 14, 77-93. DOI: 10.4995/wrs.2006.553

Trocino A., Xiccato G., Majolini D., Fragkiadakis M. 2008. Effect of cage floor and stocking density on growth performance and welfare of group-housed rabbits. Proc. 9th World Rabbit Congress, Verona, Italy, 1251-1255. 
Turner V.P., Buijs S., Rommers J., Tessier M. 2017. Code of practice for the care and handling of rabbits: Review of scientific research on priority issues. National Farm Animal Care Committee, Québec, Canada

Verga M., Zingarelli I., Heinzl E., Ferrante V., Martino P.A., Luzi F. 2004. Effect of housing and environmental enrichment on performance and behaviour in fattening rabbits. Proc. 8th World Rabbit Congress, Puebla, Mexico, 1283-1288.

Verga M., Luzi, F., Carenzi C. 2007. Effects of husbandry and management systems on physiology and behaviour of farmed and laboratory rabbits. Horm. Behav., 52, 122-129. DOI: 10.1016/j.yhbeh.2007.03.024

Verga M., Luzi F., Petracci M., Cavani C. 2009. Welfare aspects in rabbit rearing and transport. Ital. J. Anim. Sci., 8, Suppl. 1, 191-204. DOI: 10.4081/ijas.2009.s1.191

Villafuerte R., Moreno S. 1997. Predation risk, cover type, and group size in European rabbits in Donana (SW Spain). Acta Theriol., 42, 225-230. DOI: 10.4098/AT.arch.97-23

Villafuerte E.R., Kufner M.B., Delibes M., Moreno S. 1993. Environmental factors influencing the seasonal daily activity of European rabbit (Oryctolagus cuniculus) in a Mediterranean area. Mammalia, 57, 341-347. DOI: 10.1515/mamm.1993.57.3.341

Xiccato G., Verga M., Trocino A., Ferrante V., Queaque P.I., Sartori A. 1999. Influence de l'effectif et de la densité par cage sur les performances productives, la qualité bouchère et le comportement chez le lapin. Proc. 8émes Jour. Rech. Cunicole, Paris, France, 59-62.

Xiccato G., Trocino G., Majolini D., Tazzoli M., Zuffellato A. 2013. Housing of growing rabbits in individual, bicellular and collective cages: growth performance, carcass traits and meat quality. Animal, 7, 627-632. DOI: 10.1017/S175173111200198X

Zarrow M.X., Farooq A., Denenberg V.H., Sawin P.B., Ross S. 1963. Maternal behaviour in the rabbit: endocrine control of maternal nest building. J. Reprod. Fertil., 6, 375-383.

Zarrow M.X., Denenberg V.H., Anderson C.O. 1965. Rabbit: frequency of suckling in the pup. Science, $150,1835-1836$. 